\title{
腟式子宮全摘術に対する腹腔鏡の役割 The role of laparoscopy for vaginal hysterectomy
}

\author{
有田市立病院産婦人科 \\ 橋本市民病院産婦人科* \\ 西 丈則、古川健一* 、生駒 誠
}

\section{緒 言}

良性子宮疾患における子宮全摘術に腹腔鏡下手 術が提案されて久しい。われわれはこれまで経腟 的子宮全摘術を主におこなってきたが本法には経 腹手術に比し、術野が狭くまた術前に腹腔内の所 見が得られにくいという決定的に不利な条件が存 在した。これら不利な条件を補う方法として腹腔 鏡下腟式子宮全摘術をおこなった。また主に勘と 経験にたよってきた腟式子宮全摘術に対し、腹腔 鏡を補助として用いることで腹式子宮全摘術が選 択されていた症例が、より安全、確信的に腟式子 宮全摘術を完遂することができる症例が増加し、 ひいては患者の生活の質（QOL）を高める手術 になったと考えられた。本稿では、一般的に腟式 子宮全摘術が不適と考えられる症例に対しわれわ れのおこなう腹腔鏡下腟式子宮全摘術につき報告 する。

\section{方 法}

手術対象：内診所見、既往歴あるいは検查所見 （超音波検査、MRIなどの画像診断）で癒着を疑 わせる所見、開腹術の既往、内診時 2 指以下を通 ずるのみの腟管狭小等が存在すると判断した症例 を対象とした。子宮附属器を摘出するか否かは今 回の手術適応決定に影響を及ぼさなかった。

手術手順：まず臍部より腹腔鏡を挿入し腹腔内を 観察した。腹腔内に癒着が存在すれば操作鉗子を 追加挿入し腹腔鏡下に癒着剥離をおこなった。腹 腔鏡下の操作は子宮および子宮附属器周囲の癒着 剥離操作のみとし、卵管、固有卵巣索、子宮円索 あるいは卵巣提索、仙骨子宮勒帯、あるいは子宮
動脈等を腹腔鏡下に処理しないことを原則とし た。以上の剥離操作の後、腟式子宮全摘術をおこ なった。ダグラス窩に瘉着のある症例での腟式子 宮全摘術は、腹腔鏡下で同部の癒着剥離をおこな ったとはいえ経腟的に腹腔内に至るには臟器損傷 を起こさないよう手技的注意が必要である。その 1法としてこれまで一般的におこなわれていた子 宮頸部輪状切開による腹腔内に至る方法に加え、 われわれは子宮頸管切開法 ${ }^{1-3)}$ (cervicocolpotomy) を適宜応用しより安全な腹腔内到達をおこなって いる。また、適応のある症例には子宮摘出時に子 宮附属器摘出を経腟的におこなった。その後、腟 管を閉鎖し、再度腹腔鏡下に腹腔内を観察し手術 を終えた。

\section{結 果}

上述の条件を満たした 44 症例に腹腔鏡補助下に 腟式子宮全摘術を行った。手術に至った病名を表 1 に、腹腔鏡を用いた理由を表 2 に示す。その主 な理由は、癒着疑いであり、そのうちわけは開腹 手術の既往（23例）、子宮内膜症病変の疑い（8 例）、およびその他の原因による腹腔内癒着の疑 表 1 手術適応疾患

\begin{tabular}{lc}
\multicolumn{1}{c}{ 病名 } & 症例数 \\
\hline 子宮筋腫 & 34 \\
子宮腺筋症 & 11 \\
チョコレート襄腫 & 7 \\
その他の卵巣腫瘍 & 9 \\
C I N 3 3 & 2 \\
子宮内膜ポリープ & 1 \\
\hline
\end{tabular}


表 2 腹腔鏡を用いた理由

\begin{tabular}{|c|c|c|}
\hline \multirow[t]{3}{*}{ 癒着疑い } & 開腹手術既往（2 3) & \\
\hline & 子宮内膜症（8） & \\
\hline & その他の原因による癒着（9） & 40 \\
\hline 卵巣腫瘍 & & 2 \\
\hline 腟管狭小 & & 2 \\
\hline 計 & & 44 \\
\hline
\end{tabular}

い（9 例）であった。開腹手術既往のある23症例 のうち腹腔鏡下に剥離操作を要したものは15例 $(65 \%) 、$ 開腹手術既往があり術前に癒着を疑った にもかかわらず腹腔内癒着が存在しなかった症例 は 8 例 $(35 \%)$ であった（表 3 ）。腹腔鏡下に剥 離操作を要した20症例（全体の45\%）のうち開腹 手術既往のあったのは15例 $(75 \%)$ 、開腹手術既 往のなかったものは 5 例 $(25 \%)$ であった（表 3 )。 腟管狭小の 2 例と卯巣腫瘍が主病変で子宮全摘を 併用した 2 例は癒着疑い以外で腹腔鏡を施行した ものであり、これらを除いた開腹既往のない17症 例中腹腔内癒着の認められた症例は 5 症例 $(29 \%)$ で、これら症例はいずれも子宮内膜症病変か卵巣 腫瘍を合併していた。卵巣腫瘍の核出や摘出など 子宮附属器への操作を要した症例は17例 $(39 \%)$ 存在したがこれら全症例とも経腟的に処理するこ とができた。

\section{表 3 開腹手術既往と癒着の有無}

\begin{tabular}{rrrrr}
\multicolumn{5}{c}{ 癒着剥離 } \\
\hline & & あり & なし & \multicolumn{1}{c}{ 計 } \\
\hline 開腹手術既往 あり & 15 & 8 & 23 \\
& なし & 5 & 16 & 21 \\
\hline & 計 & 20 & 24 & 44 \\
\hline
\end{tabular}

その他のデー夕を表 4 に示す。平均年齢42歳 (33-76歳)、手術時間150.5 土52分、子宮重量 $197 \pm 101 \mathrm{~g}$ 、出血量 $326 \pm 197 \mathrm{~g}$ であった。今回経 験した 44 症例のうち 3 例 $(6.8 \%)$ が開腹手術へ と移行した。開腹手術移行理由は、強度の腹腔内 癒着 2 例、止血困難 1 例であった。また、膀胱や 消化管損傷、術後出血、腸閉塞などの術中術後合 併症は皆無であった。

表 4

\begin{tabular}{|c|c|c|c|c|}
\hline & 平均 & 標準偏差 & 最小值 & 最大値 \\
\hline 年齢 & 42 & 6.6 & 33 & 76 \\
\hline 経産回数 & 2.3 & 0.9 & 0 & 4 \\
\hline 手術時間（分） & 150 & 52 & 68 & 260 \\
\hline 出血量（g） & 326 & 197 & 50 & 860 \\
\hline 摘出子宮重量 (g) & 194 & 102 & 50 & 480 \\
\hline
\end{tabular}

\section{考察}

胵式子宮全摘術単独に比し腹腔鏡下胵式子宮全 摘術は腹腔鏡で腹腔内を観察でき、その際病変が 観察されれば腹腔鏡下に処置も施すことができ る。また、今回の検討でも明らかのように術前検 査で胵式子宮全摘術あるいは腹腔鏡下胵式子宮全 摘術が可能であるかの評価を正確に判定すること は難しい"）。われわれはいわゆる術前検査および 手術直前の麻酔下に行われる内診所見 (EUA: examination under anesthesia）で骨盤腹膜炎の 既往、下腹部の手術既往、あるいは子宮内膜症症 例など腹腔内瘉着が推定される症例および腟式子 宮全摘術のみでは手術が困難と想定される症例に 腹腔鏡補助下の胵式子宮全摘術をおこなった。今 回の腹腔鏡下胵式子宮全摘術とは腹腔鏡による腹 腔内観察と剥離操作とし（図 1 および図 2 )、ま た良性卵巣襄腫症例では内容物吸引し腫瘍の縮小 化を図った後に胵式子宮全摘術をおこなった。い わゆる腹腔鏡下胵式子宮全摘術でおこなわれる子 宮底部周囲の処理（卵管、固有卵巣索、子宮円索 あるいは卵巣提索などの切断)、あるいは子宮頸 部周囲の処理 (子宮動脈、仙骨子宮勒帯、腟管の 開放など）は腹腔鏡下に処理しなかった。腟式手 術を習得した術者であれば、子宮周囲の癒着を剥

図 1 子宮内膜症によるダグラス窩の閉塞

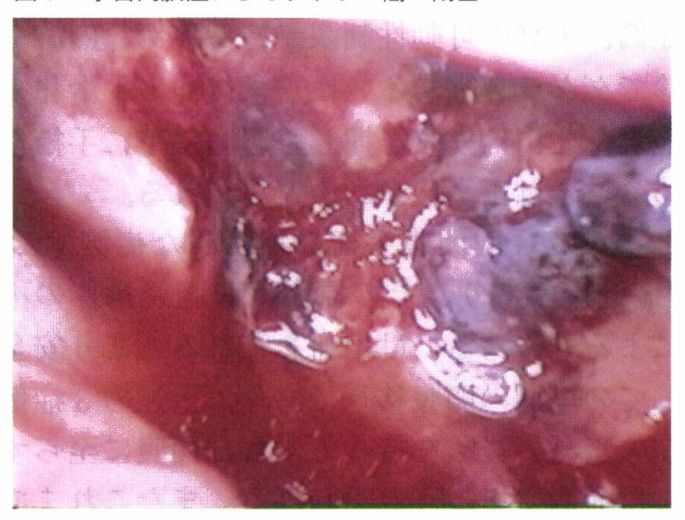

図 2 癒着剥離後ダグラス窩を開放

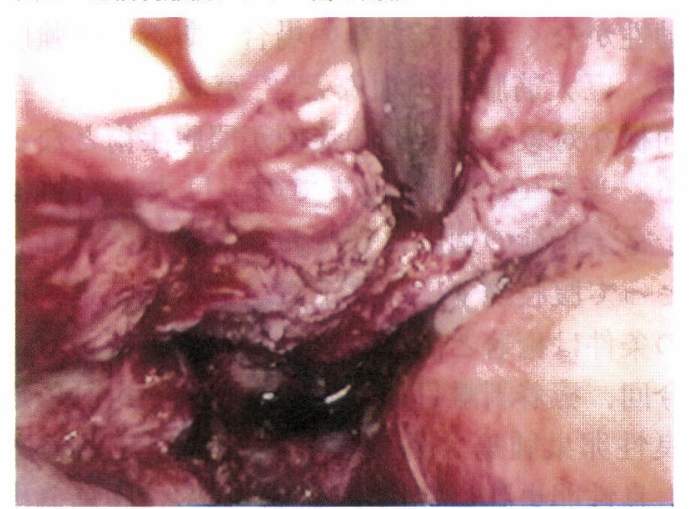


離し、子宮の可動性をある程度回復させれば腟式 子宮全摘術を完遂できるとの考えのもとに腹腔鏡 下の操作を最小限にした手技である。このことに より子宮附属器や子宮頸管周囲の処理のために金 属staplerを使用したり、血管や組織を凝固、止 血、切断するための高価な機材を用意する必要は なく、かつ腹腔鏡手術で要求される止血、結紮、 剥離操作は最小限となり、腹腔鏡手術に不慣れな 術者にも、開腹手術のみあるいは腟式手術のみの 欠点を補った低侵襲でより安全な手術を行うこと ができる。

Lundberg $ら^{5)}$ は診察で異常所見の得られた症 例の35\%は腹腔鏡で観察すると何ら異常が検出さ れなかったという。またKovacら ${ }^{4)}$ は既往歴、診 察所見、超音波診断などより得られた術前臨床診 断はその正診性に問題があり、よってそこから得 られた子宮摘出経路決定にも問題ありとしてい る。今回、開腹術既往がなく瘉着を疑った症例の うち腹腔鏡下で癒着が認められなかった症例は $70 \%$ 、開腹術既往があり癒着を疑った症例のうち 癒着が認められなかった症例は $35 \%$ あったた。か くのごとく腹腔内癒着を術前に正確に診断するこ とは難しく、どのような所見を呈する症例に腹腔 鏡を使用すべきかの明確な基準を規定することは できなかった。ただ子宮内膜症、開腹手術既往あ るいは腹膜炎既往があり診察所見で瘉着が疑われ る症例、子宮の可動性制限がある症例、内診や直 腸診でダグラス窩あるいは子宮後面の平滑化の消 失症例などには安全を期して腹腔鏡下に手術をす すめることは正当性があると思われる。

ところで今回開腹手術に移行した症例は $6.8 \%$ （ 3 症例）であり、その原因は腹腔鏡操作の不慣 れによるものあるいは出血を怖れるあまり安全を 期しての早期の開腹移行であり、上述の 3 症例は 現在の当科の経験を持ってすれば開腹に至らずに すんだ症例であろうと思われる。またこれまでの 報告では、開腹術になる原因として子宮附属器に 可動性がなく到達できない場合4) あるいは強度の 癒着、巨大筋腫と出血など,7) があげられ、今回 と同様な対象で約 $9 \%$ 症例が開腹手術となって いる。当科では約 $1 \mathrm{~kg}$ までの（巨大）筋腫は腟 式子宮全摘術の適応としており、よってわれわれ にとって腹腔鏡下に胵式子宮全摘術を完遂するた めの条件は癒着と出血のコントロールである。

今回、癒着剥離目的以外の腹腔鏡利用対象症例 は良性卵巣腫瘍合併症例と胵管狭小症例であっ た。良性卵巣腫瘍症例では、経腟的に腫瘍摘出す
るには腫瘍が大きすぎ、卵巣腫瘍内容物を吸引縮 小したのち経胵的に子宮および卵巣腫瘍を摘出、 かつ術前検查で判明しなかった癒着などの病態が ないかを観察することであった。臸管狭小例では、 経腟的に子宮全摘ができないと判断された時、次 の手段として腹腔鏡下腟式子宮全摘術をおこなう ためであった。これらの症例はともに所期の目的 を達することができた。

今回提示した腹腔鏡下手術は腟式子宮全摘術の みに比し手術時間は長くなるが、安全に腟式手術 を完遂できた。また患者の Q O L や手術侵襲を考 えれば開腹手術に比しょり優れた術式と考えられ た。ただ胵式子宮全摘術のみでも完遂できる症例 に対し、安易に腹腔鏡を併用した術式を選択する 一部風潮には、術者の良識と技量の研鑽を期待し たい。

\section{文 献}

1 ）西丈則：腟式子宮全摘術の工夫 一子宮頸管切開 法（cervicocolpotomy）によるダグラス窩腹膜開 放法一. 和歌山医学、56:211-214,2005

2 ) Pelosi III MA, Pelosi MA: A new method of completing the difficult vaginal phase of laparoscopicassisted hysterectomy. J Am Assoc Gynecol Laparosc 2:247-253,1997

3 ) Pelosi III MA, Pelosi MA: Simplified vaginal hysterectomy. N J Med 94:33-39,1997

4) Kovac SR, Cruikshank SH, Retto HF: Laparoscopy-assisted vaginal hysterectomy. J Gynecol Surg 6:185-193,1990

5 ) Lundberg WI, Wall JE, Mathers JE: Laparoscopy in evaluation of pelvic pain. Obstet Gynecol 42:872-876,1973

6 ) Richardson RE, Bournas N, Magos AL: Is laparoscopic hysterectomy a waste of time? Lancet 345:36-41,1995

7 ) 竹田明宏、他：子宮筋腫に対して腹腔鏡併用腟式 子宮全摘術（LAVH）を併用した 360 症例の検討. 日産婦内視鏡学会誌、19:60-64,2003 